\title{
Framework to measure Community Information Literacy among rural citizens in Sri Lanka: building of a CIL Model
}

\author{
Dr. Wathmanel Seneviratne, \\ Librarian, P.O.Box 21 \\ Open University of Sri Lanka \\ Nawala, Nugegoda. \\ Sri Lanka. \\ Tel:94 112805476 \\ email:wsene@ou.ac.lk
}

\begin{abstract}
The study is based on a survey conducted in rural areas of Sri Lanka on information needs and the citizens' ability to grasp the same. The study attempts to identify components of IL concept and tries to buildup an Information Literacy Model relating to rural communities. It was able to derive through the survey, factors that affect the level of IL. It was found that, competency level of IL not only depends upon language literacy or on conventional education system, but on other social factors as well. The research establishes the fact that Information Literacy is a 'living concept', as phases of IL and factors that affect to its behaviour changes person to person and environment to environment.
\end{abstract}

Keywords: Rural Community Information, Community Literacy, Rural Information Flow, Literacy Variables, Literacy Frame, Assessment Frame

\section{Introduction}

The history indicates that the human beings had passed many revolutionary eras and shift of these periods to the next was much attributed to the change of knowledge levels of the man. Modern society is said to be highly information dependent and almost all social activities nowadays are information, knowledge and learning oriented. Information Society is a term used for a society in which the creation, distribution, and manipulation of information has become the most significant economic and cultural activity. People in the modern society regardless their geographical, racial, educational and social differences are in need of a variety of information and rural dwellers are equally enthusiastic in obtaining information for their day today lives, as are urbanites, according to Uhegbu (1997).

It is seen that in any traditional or modern society an information and communication flow exists. It has a social behaviour specific to the embedded values in that particular society. It is also a right of a citizen of any social status to obtain the information he needs to adapt to the modern life style. On the other hand, it is the duty of the government to plan necessary infrastructure to provide information to all the communities scattered all over the country including rural areas. When it comes to information scenario in modern terms, it was observed that there are some barriers for smooth and effective flow of information. The scope of the main study where this paper is extracted evolves around rural society, making rural community information scenario at the focus. One barrier that was emerged through the study was 'low level of information literacy', despite the higher language literacy rate counted in Sri Lanka including rural areas. 


\section{Community Information}

Community information was described by Pienaar as, information needed for living and information needed to participate in social activity (Pienaar, 1994). According to the modern citizenship rights, access to information is a basic right of a citizen (Marcella \& Baxter, 2000). Citizenship information also attributed to the community information which is needed by general public and produced by national or local government, government departments and public sector organizations (Marcella \& Baxter, 2000).

According to the main part of the present study conducted in 10 remote villages (samples drawn through multi stage cluster sampling method), it was identified two main categories of Community Information;

1. Needs required commonly by all citizens (Common Needs)

2. Specific information to meet special needs ( Specific Needs)

Finding of the study identifies the nature of Community Information as;

- created by government and related institutions

- non-bibliographic

- unpublished

- not actively captured by standard documentation services

- Mostly sought after by ordinary communities for their livelihood development.

It was also noted that this special kind of information cannot be comprehensively supplied by the public library system available in Sri Lanka. It was found that the reasons for the situation are; mainly due to the absence of established internet connectivity, absence of systematic government information provision, lack of information integration among the government information sector etc.

\section{Information Literacy in Sri Lanka}

In Sri Lanka $85.49 \%$ population live in rural and estate areas even though urban migration occurs constantly over the years (Census \& Statistics, 2004). Working population in these areas both male and female accounts $49.6 \%$ of the total rural working population. The main occupation of these rural and estate areas is predominantly agricultural and informal. Educational attainment index in three sectors (urban, rural, estate) shows an increasing trend and is not very low when compared with the urban index.

According to 1999 figures, literacy rate is 94.5 in the urban sector and $92.3 \%$ in the rural sector (Dept. of Census \& Statistics 1999, Central Bank of Sri Lanka 1999). These indicators shows that there is a significant social and cultural upcoming among the rural and estate sector even though the social amenities are not provided equally for them as for the urban sector. However, the literacy level of the rural sector is close to the level in the urban sector. 


\section{Conceptual approach for IL}

The concept of information literacy emerged through US and Australian education theory and librarianship. Information Literacy directly deals with competency level of using set of information skills and is treated as an essential requirement for every citizen to be a 'rightful and informed' citizen. The citizen, as an element in any community, cannot derive expected productive results from the information component provided if the person does not have the skill to absorb the same. When considering the 'community information' category, which has much emphasis on livelihood development, will become stagnant, if the information skills are not developed within communities.

The situation is not claiming from the 'information gap' that exists in the rural areas due to mismatch of the information supply and the demand for information, but the situation claims from the 'knowledge gap' that exists among ordinary communities, due to inability to access and derive expected fact or information component from the information provided. This situation is disastrous than not having or not being provided with information, as non-provision of information can be closed by providing information, but the latter address to more complex situation that deals with more socio-cultural, political, educational and technical issues. In some cases these issues cannot be addressed without having drastic changes in policies. Gravity of the problem will be clarified to some extent under the Information Literacy Frame discussed in this paper.

It is important to understand the difference of two concepts, 'information seeking behaviour' and 'information literacy'. It is seen that the standard steps identified in the two processes are almost identical. The difference of these two concepts is, former deals with steps followed physically by an information seeker, while the latter deals with the knowledge levels that a information seeker need to achieve to use the steps in the former process effectively (Seneviratne, 2004). There are many definitions for the term 'information literacy'. The most comprehensive is that of the American Library Association, which defined the concept as,

"...a set of abilities requiring individuals to recognise when information is needed and have the ability to locate, evaluate, and effectively use that information for the issue or problem at hand" (NFIL \& ALA-PCIL,2003).

IL is central to most of the other skills. As Denis Ralph adopts from Bruce's model, IL is not a concept which stands alone, but is a central skill contributed by other supporting skills (Ralph,1999). According to Ralph, Information skills, computer literacy, IT literacy, library skills and learning to learn contributes to IL. Many other authors and researchers of information seeking behavior had contributed to the concept with greater insight into the theory of learning. Theories and models established in the scope of information skills, information retrieval /searching process and behavioural theories of information seeking were earlier developed upon learning theories. For instance Blooms Taxonomy of Learning Outcomes was introduced in 1956 and is still being used as a base for analyzing learning levels. Mentioned below are the Some of the theories and models established in the scope of information skills, information retrieval /searching process and behavioural theories of information seeking;

- Blooms Taxonomy of Learning Outcomes introduced in 1956 (Bloom 2003)

- Eizenberg and Berkovitz's Big 6 model (Eizenberg \& Berkovitz 1990)

- Tom Wilson's information seeking behaviour models (Wilson,1999), 
- Kuhlthau's models of information seeking behaviour (Kuhlthau,1991,1998)

- Bruce's Relational Model of Information Literacy (Bruce,1997)

- SCONUL (Society for Collage and University Libraries) UK, 7 Pillars of Information Literacy Skills (or 7 headline skills) model (SCONUL, 1999)

- Ontario School of Library Association -EXIT Model of College level student literacy (OSLA,1999)

- Ralph's model of Information Literacy (Ralph, 1999)

- Penny Moore's 6 stages of Information Problem Solving (Moore 2002)

- Prague Declaration - (UNESCO,NCLIS,NFIL,2003)

- Empowering 8 - (NILIS, University of Colombo, 2005)

It is interesting to note that the concept has different angles of interpretations when deals with different environments. For instance IL for pedagogical environment is different from workplace or adult literacy issues (Winterman, Skelton \& Abell 2003, TFPL,1999, Donnelly \& Craddock,2002). Among the many conceptual frameworks mentioned above on IL, the present paper use IL standards set forth in the "Prague Declaration" to develop CIL Frame for rural communities. The participants in the Prague convention agreed that an 'information literate citizenry' is required to mobilize an effective civil society and create a competitive work force. Participants declared that $\mathrm{IL}$ is a basic human right for Life Long Learning.

Fig.1 - Prague Declaration - (UNESCO,NCLIS,NFIL,2003)

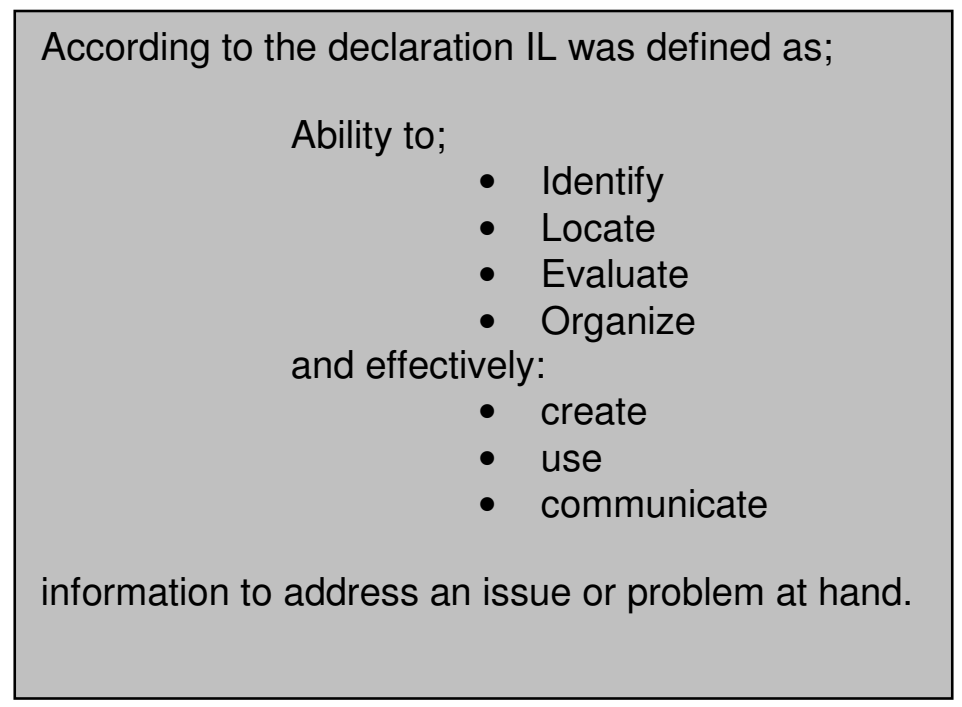

According to Zurkowski, people trained in the application of information resources to their work can be called information literates (Zurkowski in Spitzer, Eizenberg \& Lowe, 1998). It is noteworthy however that, IL is a skill that can be propagated in people and are to be trained to be information literates. Also the IL skills will be developed in person is not similar to another person who had undergone similar training or belonging to the same environment. Hence IL skill is specific to an individual. Thus the set of skills as mentioned in the Prague frame change, from environment to environment, person to person depending on impact level of some factors revealed in the study, such as personal status, intelligence level of person, information access systems established, infrastructure issues etc. Prague IL frame is a generalized model 
and do not stick to a category of people or community in particular, but talks about the need of information literate citizenry at large. The frame (Prague IL frame) is used as the base concept in building rural Community IL model through the present study.

\section{Assessing the Information Literacy}

According to the situations and complexities of the communities studied in the present research, some situations are identified as additional variables other than the variables mentioned in the Prague frame.

\section{Variables identified through the survey}

Following are the specific situations observed during survey:

a) Lack of or no awareness about an Information Gap - Lack conception of the Information Need - about $78 \%$ of the respondents interviewed are not aware whether an information need had arisen. Out of $78 \%$ of the respondents about $15 \%$ thought (most of them were older people) that what they know was more than enough to lead the rest of their lives. Hence the attitude towards obtaining information is 'non responsive', almost 'Cold'.

b) Lack of or no understanding about obtaining information ( Closing the information gap) by accessing to information sources. About $30 \%$ of the respondents have not communicated the need to any proper information provider or channel except to his members of own household or close relatives. About $20 \%$ contacted the neighbor, again not sure about whom to be contacted to obtain information. About $18 \%$ use knowledge what they already had or as a habitual practice, hence accurate information was not reached by them. About $18 \%$ depend upon radio or TV, again no comprehensive coverage on all sorts of needs was fulfilled and due to listening habits. $14 \%$ did not express the need to obtain information to anybody or confused about obtaining information.

c) Lack of or no awareness about the usability, practicality or appropriateness of information obtained (Evaluation of information) - The measurement of this concept highly varied according to the need category. The respondents, before use, were always evaluated some categories of information, which were long associated with the respondents such as employment related, economic activity related or vocation related. But some information which were not used much or not very familiar to them, were not been evaluated by them due to lack of conversancy or knowledge on the same. Hence about $65 \%$ of the respondents were mentioned that they were 'mislead' in obtaining information, which indicates the respondents have no stability to evaluate information. It was only $15 \%$ told that information is not comprehensive enough to use or not practical. Rest gave different reasons like 'unclear information', 'not sure' etc.

d) Lack of knowledge about information exchange ( Information Transfer) The response again highly varied upon the information category. They exchanged the information if much familiar to them and transferred informally, at day today chats, at village boutique, suppliers shop etc. Some information like health related issues, industrial aspects, education and training, 
government information, financial, legal etc. were rarely transferred at village level, but a person who obtained it directs the other to an appropriate channel where the required information could be obtained (Seneviratne 2004).

These characteristics of the communities identified ( $a, b, c$ and $d$ above) are summerised in the Table 1.

Table 1: Variables considered newly into Prague Frame

\begin{tabular}{|c|c|}
\hline Base Skill & $\begin{array}{c}\text { Components (are the Variables used in the } \\
\text { analysis) }\end{array}$ \\
\hline $\begin{array}{l}\text { (a \& b) Prior knowledge } \\
\text { about information need }\end{array}$ & $\begin{array}{l}\text { 1. Awareness and knowledge about that an } \\
\text { information need has arisen } \\
\text { 2. Awareness on that there is an } \\
\text { Information gap } \\
\text { 3. Awareness on that Gap can be closed } \\
\text { through information }\end{array}$ \\
\hline $\begin{array}{l}\text { (c)Effective usage of } \\
\text { information }\end{array}$ & $\begin{array}{l}\text { 4. Understanding usability /practicality of } \\
\text { information once obtained }\end{array}$ \\
\hline (d) Communication & $\begin{array}{l}\text { 5. Communicate or guide others on the } \\
\text { same problem }\end{array}$ \\
\hline
\end{tabular}

The left column of the table depicts the evaluative base elements and on the right cages sub components relating to base element are indicated as derived from the survey.

\section{Building up Community IL (CIL) Model}

Though the Prague Frame was used as the theoretical base, there were community specific characteristics that are essential to be incorporated in to the model as identified in Table 1. These base skills are almost common to ordinary thinking level and realization level of any individual in any ordinary community. See Table 2 for the list of integrated set of skills /variables that form the CIL frame. 
Table 2: List of integrated set of skills /variables

\begin{tabular}{|c|c|}
\hline Base Skill & Components (Variables used in the analysis) \\
\hline $\begin{array}{l}\text { Prior knowledge about } \\
\text { the need for } \\
\text { information (BK) }\end{array}$ & $\begin{array}{l}\text { 1) Awareness and knowledge about that an } \\
\text { information need has arisen (KI) } \\
\text { 2) Awareness on that there is an Information } \\
\text { gap(IG) } \\
\text { 3) Awareness on that Gap can be closed } \\
\text { through information(GC) }\end{array}$ \\
\hline Information needs (IN) & $\begin{array}{l}\text { 4) Identify the categories of information needs } \\
\text { (IC) }\end{array}$ \\
\hline Information Seeking (IS) & $\begin{array}{l}\text { 5) Location of channels to reach information } \\
\text { source(IL) } \\
\text { 6) Methods of approaching /obtaining the } \\
\text { information (IS) }\end{array}$ \\
\hline $\begin{array}{l}\text { Effective usage of } \\
\text { information (EI) }\end{array}$ & $\begin{array}{l}\text { 7) Understanding usability /practicality of } \\
\text { information, once obtained- } \\
\text { Appropriateness (IP) } \\
\text { 8) Use of information (IU) }\end{array}$ \\
\hline Communication (Cl) & $\begin{array}{l}\text { 9) Information Transfer -(IT) } \\
\text { 10) Information Exchange - (IX) } \\
\text { ( Communicate or guide others on the } \\
\text { same or related problem) }\end{array}$ \\
\hline
\end{tabular}

The skills identified are integrated into a common frame (Table 2) to depict how a person behaves through the IL process when an information need had arisen. The skills need to achieve IL level are depicted below as a function indicating, how the variables mentioned in Table 2 determine the CIL level of a person, during a given information search at a given time in a given community. The functional statement indicates, any change in any variable cause a change in the literacy level of a person belongs to a particular community.

$$
C I L=f(B K), f(I N), f(I S), f(E I), f(C I)
$$

Where, $\quad \mathrm{ClL}=$ Community Information Literacy

BK = Base knowledge about the need

IN = Information Need category

IS = Information Seeking Behaviour

$\mathrm{EI} \quad=$ Effective Usage of Information

$\mathrm{Cl}=$ Communication of Information obtained 


And, $\quad \begin{aligned} B K & =K I+I G+G C \\ I N & =I C \\ I S & =I S+I L \\ E I & =I P+I U \\ C I & =I T+I X\end{aligned}$

Where, KI,IG,GC,IC,IS,IL,IP,IU,IT,IX are equal to the descriptions given for each variable in right column of the Table 2.

For example when BK, the base knowledge about the information need is low, literacy level will also be adopting low value accordingly as the BK will be affecting adversely, thereafter through out the process. When the BK is high it affects to increase the level of IL. Likewise all the other functions has a functional relationship with the CIL level. The CIL is a composite of functions of individual elements and not a function of all the elements $(C / L=f(B K \ldots C)$.

When all the variables are categorized into broad areas as given below in Frame 2, using 10 variables mentioned in Table 2, indicate how the skill levels indicated form a set of steps that are to be passed in attaining IL level. It also depicts that how these steps passed lead a person's awareness into certain knowledge levels.

Fig. 2: Community Information Literacy Model (CIL)

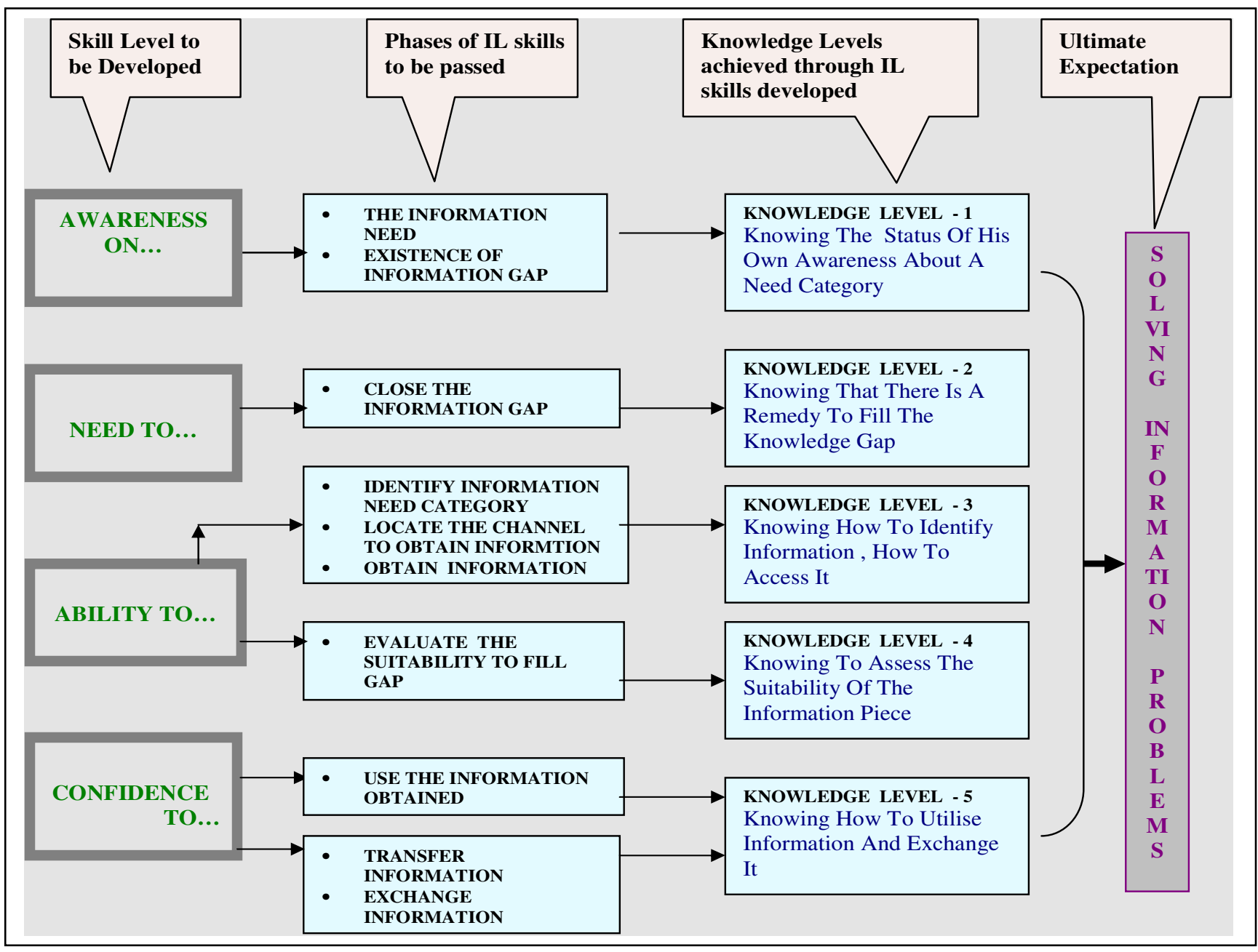


Fig. 3: Skills developed by the information literate person

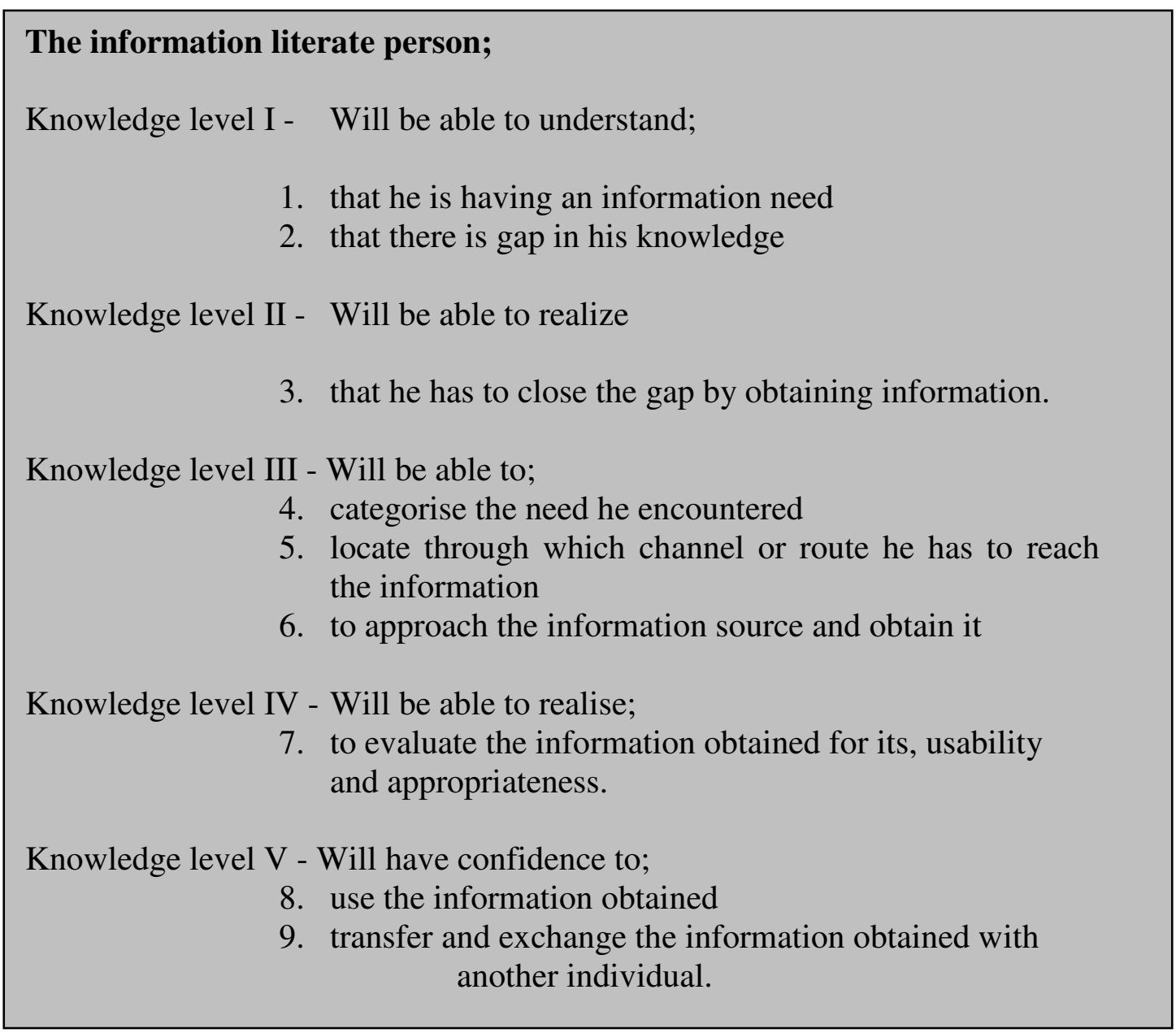

\section{Conclusion}

The paper attempted to clarify the situations and challenges faced by the ordinary person belong to any rural or any other community group in obtaining information for their day to day livelihood development in an actual environment. The variables pertaining to the information literacy levels were derived through a survey conducted in 10 districts. Other than the variables identified in the Prague frame the study identified a set of basic skills that determines the effective use of skill level need to be developed consecutively. It was also observed as the IL skill level developed there is a set of affiliated knowledge levels that will be propagated in the information seeker due to upgrading of information literacy skills. These knowledge levels are also the outcomes expected by propagating IL skills among citizens. As a future research space, these knowledge levels can be compared with the behavioural patterns of the citizens and the level of accomplishment of objectives of obtaining information. It is also important to research how the information flow in a community will be patterned and affected through the development of information skills within its members. However it was revealed through the study that the CIL level remarkably change upon the nature of the information need, status of the person and the 
situation in the environment he belong at the very point of the information need had arisen. Therefore the research establishes the fact that Information Literacy is a 'living concept'.

\section{References:}

Big6 ${ }^{\mathrm{TM}}$ Home page (2004) http://www.big6.com/showcategory.php?cid=6

Blooms, B.(2003) Learning skill program - Bloom's Taxonomy http://www.coun.uvic.ca/learn /program/ hndouts/bloom.html

Bruce, C. (1997) Seven faces of information literacy. Adelaide: Auslib Press.

Bruce, C. (2004) Information literacy: a phenomenography. Abstract of the PhD thesis (1996). http://sky.fit.qut.edu.au/ bruce/inflit/thesis.php

CAUL (2001) Information literacy standards. $1^{\text {st }}$ ed. Council of Australian University Librarians. Canberra.

Eizenberg M. and Berkowitz B. (1990) Information Problem Solving : The Big 6 approach to library and information skills instruction. Ablex .

Final Report of the American Library Association. Presidential Committee on Information Literacy. American Library Association, 1989.

Kululthau C.C. (1998) A principal of uncertainty of information seeking. J. of Documentation. 49(4) pp.5-20.

Kululthau C.C.(1991) Inside the search process: information seeking from the user's perspective. JASIS, 42 (5) pp.361-371.

Mchombu, K. (1996) Impact of information on rural development; background, nethodology and progress. Project paper. IDRC. www.idrc.ca/books/focus/783/mchombu.html

Moore, P (2002) Information Literacy in school librarianship. Workshop conducted at National Institute of Library \& Information Science, University of Colombo. Colombo.

NFIL, ALA \& PCIL (2003)National Forum on Informaiton Literacy -American Library Association, Presidential commission on Information Literacy.

http://www.infolit.org/

Ontario School Library Association (1999) Information Studies : Kindergarten to Grade 12: The EXIT Model. Toronto; Ontario School Library Association.

People.mills.edu (2004) Information Literacy - the pathway to the future (http://www.people.mills. edu/cmaybee /Lresources.htm

Ralph D. (1998) Information Literacy and foundation Life Local Leadership. In Proceedings of the $4^{\text {th }}$ National Information Literacy Conference. UNISA, Library Society. Adelaide. 
SCONUL (1999) Information skills in higher education: a SCONUL position paper. London : (SCONUL) Society for College, National and University libraries.

Seneviratne,W. (2004) Laying paving stones for a knowledge society: Community Information Literacy $(\mathrm{CIL})$ and an analysis of barriers to upgrade CIL in rural Sri Lanka. Paper submitted at $75^{\text {th }}$ IFLA Conference, at Asia and Oceania Section. Buenos Aires. pp.1-25.

Spitzer, K. L., Eisenberg, M. B. and Lowe, C. A.(1998) Information Literacy: essential skills for the information age. ERIC Clearinghouse in Information \& Technology, New York.

Sturges ,P.,Chimseu ,G,(1996) The chain of information provision in the village of Malawi :A repaid rural appraisal .International Information \& Library Review,pp135-155.

TFPL (1999) Skills for Knowledge Management: a Briefing paper by TFPL Ltd. London: Library and Information Commission.

Town, J.S. (2002) Marketing information literacy to academic communities: the work of the SCONUL Information Skills Task Force. Presentation made at the annual conference of IFLA. $18^{\text {th }}-22^{\text {nd }}$ August 2002. BITEC, Glasgow.

UNESCO,NCLIS,NFIL(2003) The Prague Declaration: 'Towards an information literate society'.UNESCO, National Commission on Libraries and Information Science(NCLIS) \& National Forum on information Literacy (NFIL).

http://www.nclis.gov/libinter/infolit conf\&meet.html

Donnelly, A. and Craddock, C.(2002) Information literacy at Unilever R\&D.Library and information update, 1 (9).

http://www.cilip.org.uk/update/issues www.ifla.org/IV/ifla69/papers/199e-Webber.pdf

Wijetunge, P. and Alahakoon, U. (2005) Empowering 8: the Information Literacy model developed in Sri Lanka to underpin changing education paradigms of Sri Lanka. Sri Lanka Journal of Librarianship \& Information Management volume 1 (1) pp.31-41

Wilson, T.D (1999) Models in information behaviour research. J. of Documentation. 55(3) June pp. 249-270.

Winterman,V., Skelton, V. \& Abell, A. (2003) Information literacy in the work force: the skills gap, and how enterprises are planning to cope. A TFPL research.

http://www.nclis.gov/libinter/infolitconf\&meet/InformationLiteracyStages Responsibilities\& OutcomesMatrix.pdf 